\title{
THE PHILOSOPHICAL STUDY OF IQBAL'S THOUGHT: \\ The Mystical Experience and the Negation of The Self-Negating Quietism
}

\author{
Alim Roswantoro \\ UIN Sunan Kalijaga Yogyakarta \\ dralim.roswantoro@uin-suka.ac.id
}

\begin{abstract}
The article tries to philosophically explore the Iqbal's notion of mysticism and the mystic's attitude in facing the world life. The exploration is focused on his concept of mystical experience and the negation of the self-negating quietism. And from this conception, this writing efforts to withdraw the implication to the passive-active attitude of the worldly life. It is the philosophical understanding of the Islamic mysticism in Iqbal's philosophy as can be traced and found out in his works, particularly in his magnum opus, "The Reconstruction of Religious Thought in Islam". Mysticism, in Iqbal's understanding, is the human inner world in capturing reality as a whole or nonserial time reality behind his encounter with the Ultimate Ego. For him, there are two experiences, that is, normal one and mystical one. In efforts to understand mysticism, one has to have deep understanding of the basic characters of human mystical experience that is very unique in nature compared to human normal one.
\end{abstract}

Keywords: mystical experience, self-negation, active selfness, making fresh world

\section{A. Introduction}

7 he great Urdu poet-philosopher, Muhammad Iqbal, influenced the religious thought of the Muslims not only in Pakistan and India, but also in Europe, Asia, and Africa

1 in many ways. His thought of political, religious and philosophical issues led him to be one of the greatest thinkers of the 20th century. He rethought and remade the fresh ideas of Islamic messages not only for his contemporary Muslim society but also for the generations to come. 
The Iqbal's religious philosophy revolves round the theory of Khüdi (ego) which came into existence as a reaction to the ways of being a Muslim in India of his Time which was mystical and fatalistic in characters. Sufism, as he thought, inspired among Muslims a passive and pessimistic outlook and attitude and thus weaned them off the life force that once drove them. Sufism anathema to Islam. As a result, they confined themselves to the monasteries. They became devoid of their national ego (Khūdi). Therefore, in his later years, Iqbal became severely opposed to Sufism and even declared Sufism anathema to Islam.

Iqbal was not a born Sufi basher. He came from a Sufi background. His father Noor Mohammad was a Sufi minded person. The great book of Ibn e-Arabi titled Fusūs al-Hikam, a Sufi treatise, was taught in his house. Ibn al-'Arabi was the greatest exponent of the philosophy of wahdah al-wujūd, the basis of Sufism. The Mathnavi of Maulana Rūmi, the great Persian poet and philosopher and the spiritual mentor of Iqbal, was also taught at his home in his boyhood. Maulana Rumi was also a believer in the philosophy of wahdah alwujüd. Beside his religious and sufistic upbringing, Iqbal also studied the western philosophies and did a comparative study of the philosophies of the world, particularly amongst the western, Indian, and Islamic philosophies. Thus, on the one side, he inherited the Sufi legacy from his family and society, and on the other side, he was well educated in the western philosophies. This brought about a revolutionary change in Iqbal's religious thought of Islam, including his belief in Sufism as an Islamic doctrine.

\section{B. The Life of Muhammad Iqbal at Glance}

Muhammad Iqbal (1877-1938) is one of the preeminent-writers of Indo-Pakistan subcontinent. Indeed, the attention he has received from numerous writers, translators and critics from western as well as Islamic countries testifies to his stature as a world literary figure. While his primary reputation is that of a poet, Iqbal has not lacked admirers for his philosophical thought. He has in fact been called the more-serious scholar philosophical thinker of modern times.

Sir Muhammad Iqbal was born November 9, 1877, in Sialkot, Punjab, India (now in Pakistan). ${ }^{1}$ He was born of a pious family of small merchants and was educated at Government College, Lahore. He received his early education in that city, Sialkot, where one of his teachers was Mir Hasan, an accomplished scholar who commanded a

\footnotetext{
${ }^{1}$ There is disagreement of Iqbal's birthday. Some said that he was born in 1873 and others in 1877 . see, Gerhard Bowering, "Iqbal: A Bridge of Understanding Between East and West" in Journal of South Asian and Middle Eastern Studies, Vol. I, No. 2, Dec. 1977, 12; Khalifat 'Abdul Hakim, "Renaissance in IndoPakistan: Iqbal” in M.M. Sharif (ed.), A History of Muslim Philosophy, vol. II (Jerman: Ottohorrosowitz, 1996), 1614; Danusiri, Epistemologi dalam Tasawuf Iqbal (Yogyakarta: Pustaka Pelajar, 1996), 3.
} 
The Mystical Experience...

knowledge of several Islamic languages. Mir Hasan gave Iqbal a thorough training in the rich Islamic literary tradition. His influence on Iqbal was formative. ${ }^{2}$

Iqbal went to Lahore in1895, for his higher education. He enrolled in Government College in 1899 and obtained a degree in law in 1898. In Lahore, in a major center of academic and literacy activity, Iqbal soon made a name for himself as a poet. One of the teachers of Government College Iqbal strongly admired was Sir Thomas Arnold. Then, Arnold had great affection for Iqbal, he helped Iqbal in his career as a teacher and also encouraged him to undertake several research projects. ${ }^{3}$

When Arnold returned to England in 1904, Iqbal wrote a touching poem in which he expressed his resolve to follow Arnold to England. The very next year, in fact, Iqbal left for study at Cambridge. His choice of Cambridge was reputed for the study not only of European philosophy but also of Arabic and Persian. In his three years of stay abroad, 1905-1908, Iqbal obtained a B.A. from barrister at London Middle Temple in 1906, and completed his doctorate program and earned a Ph.D. from Munich University in $1908 .{ }^{4}$ His dissertation, The Development of Metaphysics in Persia, revealed some aspects of Islamic mysticism formerly unknown in Europe. He died April 21, 1938, in Lahore, Punjab. ${ }^{5}$

After returning to Lahore in 1908 Iqbal taught philosophy at Government College for a few years. In 1911 he resigned from Government Service and set up legal practice. Meanwhile he continued to write poetry in Urdu and Persian, Asrar-i-Khüdi (Persian) that was published in 1915 translated to English as the secret of the self (1920) by Professor Reynold Nicholson of Cambridge. The book introduced Iqbal to the west. Asrāri-i-Khüdi was followed by several other volumes. Rumuz-i-Bikhūdi (1918), Payam-i-Mashriq (1913), Bang-i-Dara (1924), and so on. Through these works, Iqbal became well-known in European academic people. ${ }^{6}$ Then, he productively wrote his works, and, besides the already mentioned works, these are among his works: Zabūr-i 'Ajam, his Persian work published in Lahore (1927), had been translated into English by A.J. Arberry with title, Persian Psalms (1948); Six Lectures on the Reconstruction of Religious Thought in Islam, his English work puhlished in Lahore (1931), published in London (1931), and then publish by adding an article "Is Religion Possible?" with new title, The Reconstruction of Religious Thought in

\footnotetext{
${ }^{2}$ Mervin M. Keizer and Nasem Sahibzada, "Iqbal: A Profile" in Journal of South Asian and Middle Eastern Studies, Vol. I, No. 2, Dec. 1977, 5.

${ }^{3}$ Hafeez Malik dan Linda P. Malik, "Filosof-Penyair dari Sialkot" in Ihsan Ali Fauzi dan Nurul Agustina (trans. \& eds.), Sisi Manusiawi Iqbal(Bandung: Mizan, 1992), 27.

${ }^{4}$ Hafeez Malik dan Linda P. Malik, "Filosof-Penyair dari Sialkot", 35.

5 Alim Roswantoro, Gagasan Manusia Otentik dalam Eksisntensialisme Religius Muhammad Iqbal (Yogyakarta: Idea Press, 2009), 20-21.

${ }^{6}$ Iqbal Singh, The Ardent of Pilgrim: An Introduction to the Life and Work of Muhammad Iqbal (Calcuta: Orient Longmans, 1951), 60, 101.
} 


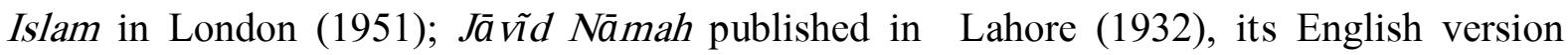
translated by A.J. Arberry with title was published in Londong (1966); Pas Cha Bāyad kard, his Persian work published in Lahore (1936); Musāfir, his Persian work published in Lahore (1936); Bāl-i Jibrĩl, his Urdu work published in Lahore (1936); Zarb-i Kafimm, his Urdu work published in Lahore (1937); The Development of Metaphysics in Persia: A Contribution to the History of Muslim Philosophy, his doctoral work in Munich (1908), published in Lahore (1964); Stray Reflection: a Note Book of Allama Iqbal, Iqbal's thought in his own handwritings edited by Javid Iqbal, published in Lahore (1961). ${ }^{7}$

Iqbal's works of poetry and philosophy do not exist separately one another. They are integrally related one another. Iqbal wrote poetry in Urdu and Persian, and several collections in each language exist. His poetry serves as a vehicle for his thought that is philosophically articulated in The Reconstruction of Religious Thought in Islam.

After a long period of ill health, Iqbal died in April 1938 and was buried in front of the great Badshahi Mosque in Lahore. Two years later the Muslim League voted for the idea of Pakistan. That the poet had influenced the making of that decision, which became a reality in 1947, is undisputed. He has been acclaimed as the father of Pakistan, and every year Iqbal Day is celebrated by Pakistanis.

Iqbal's thought of Islamic mysticism can be found in both his poetry works and philosophical ones. From the former, it can be traced particularly in Asrā ri-i-Khū di, Rumuzi-Bikhüdi, and Payam-i-Mashriq, and of course, in his poems spread in his other poetry works. From the latter, it can be derived particularly from The Reconstruction of Religious Thought in Islam and The Development of Metaphysics in Persia: A Contribution to the History of Muslim Philosophy. His Islamic mysticism is built from his rejection of classical Islamic mysticism encouraging human fatalistic deeds, and instead, he promotes the modern Islamic one encouraging human active deeds creatively involved in changing and reforming the world.

\section{Muhammad Iqbal and the Islamic Mysticism}

Tasawwuf or Islamic mystisism, according to Harun Nasution, can generally be defined as a discipline that a Muslim should learn and practice the religious paths or ways of how to bring himself closer and more intimate to God. ${ }^{8}$ For A.R. Badawi in his book Tarikh al-Tasawwuf al-Islämiy, there are two elements of Islamic mysticism, i.e. firstly, the spiritual experience within a mystic's communication with God (ittisāt) and secondly,

\footnotetext{
${ }^{7}$ Concerning the complete exposition of his works, see Annimarie Schimmel, Gabriel's Wing a Study into the Religious Ideas of Sir Muhammad Iqbal, (Leiden: E.J. Brill, 1963), 389 - 394.

${ }^{8}$ Harun Nasution, Islam Ditinjau dari Berbagai Aspeknya, (Jakarta: UI Press, 1985), 56.
} 
recognizing the encounter and unity of a sufis and God (imkān al-ittihhād). Tasawwuf or Islamic mysticism is not just knowledge of God as being who is One, but since the beginning the muslim mystics had directed themselves to unite with God. ${ }^{9}$ Al-Taftazani, in Madkhal ilā al-Tasawwuf al-Islämiy, presents some characters of tasawwuf, i.e., tașawwuf teaches purification of the soul through training to get the good morality; there should be a spiritual experience of fana', i.e., the disappearance of human consciousness of his selfness in order to enter to the next step, namely, baqā' (the constant knowledge that is intuitive (dzauqi) convinced directly coming from God; there should be peace and happiness for those who reach the spiritual experience; and that the tasawwuf's teachings are often symbolically disclosed (al-ta'bir), because it is about feeling (wujdāniyah) and personal experience (dzätiyyah). ${ }^{10}$

Iqbal seems to be objection to the sense of Islamic mysticism that is identical with fana $\bar{a}$, or the disappearance of human consciousness of his selfness. And he preferes to understand Islamic mysticism as a discipline of religious training that can purify the Muslim's soul and brings him closer and more intimate to God without loosing his self consciousness. The Muslim mystic, even when he had reached the unitary experience with God, can always consciously identify the difference between his own self and God's Self.

Iqbal is a thinker who is not anti the Islamic mysticism. There are so many denominations of the Islamic mysticism. At least, they can be simplified into two kinds of Islamic mysticism, that is, the passively Islamic mysticism and the actively Islamic mysticism. The first one maintains the concept of self-negation in the mystic's peak experience, and the second one refutes it. And Iqbal prefers to the second kind of the Islamic mysticism. To be a mystic-muslim cannot be contrasted with the Islamic message of being a Muslim individual who is characterized by the positive ego-hood ( $k h \bar{u} d i$ ). To be a good Muslim should be a mystic-muslim who always think and behave creatively and actively. The Islamic mysticism encouraged by Islam is one resulting in the mystic-muslim who is not avoiding the worldly life. Instead, he creatively and actively involved in it through the spiritual manners in order to make the good change of the world as a better place for entire people and other creatures of the world.

This conclusion can easily be known from Iqbal's insight of the practice of Islamic mysticism in India he lived. He develop the view that the Islamic Sufism or mysticism in India of his time was a distortion of Islamic Shari'ah under the influence of the Vedanta and Buddhist philosophy. Therefore, he came to the conclusion that the belief of Hinduism and

\footnotetext{
${ }^{9}$ A.R. Badawi, Tārikkh al-Tașawwuf al-Islamīy, (Makkah: Dār al-Ma'arif, 1975), 21.

${ }^{10}$ Abū al-Wafā Al-Taftāzānì, Madkhal Ilā al-Tașawwuf al-Islamìy (Kairo: Dar al-Tsaqafah, 1979), 8-9.
}

Teosofia: Indonesian Journal of Islamic Mysticism, Volume 6, Number 1, 2017 
Buddhism had crept into Islam in the guise of mysticism. ${ }^{11}$ To purge Islam of the foreign impurities, he wrote the long verses (Matsnavi), Asrā r-i-Khudi (the Secrets of Ego) which created quite a flutter among Muslims, particularly in the sufis' circles.

However, Iqbal made it clear that he was not totally opposed to Sufism. He was opposed to the Sufism that was in sync with the Vedanta philosophy. In introduction to Asrär-i-Khudi, he wrote that there is a strange resemblance between the mental history of both Hindus and Muslims so far as the research into the issue of ego is concerned. ${ }^{12}$ This had a great impact on the thoughts of the Muslims. Therefore, to purge the impurities from Sufism, he coined the term Islamic Sufism to differentiate it with the Sufism that was influenced by Hindu beliefs and practices.

Iqbal was of the view that the Sufism that was being practiced in India and other Muslim countries like Iran and Afghanistan was actually an Ajami (non-Arab) concept that had nothing to do with Islam. The characteristic features of the ajami sufism were that man's stature was reduced to lowly creatures like insects, man negated his existence in the name of annihilation into god, man considered his visible material world as an illusion, man considered life not more than a dew drop, man did not differentiate between creator and creature, man rejected Shari'ah and valued thariqah, and man crushed his self-respect. ${ }^{13}$ According to Iqbal, these cannot be the beliefs and practices of a devout and true Muslim. The Quran says that the entire universe has a real existence and the earth is also created on truth. The world is not an illusion. The philosophy of wahdat al-wujüd which is the core of Sufism says that God is one but the entire universe is a manifestation of His existence and therefore the phenomena of the universe do not have an existence of their own. ${ }^{14}$ They are merely the manifestation of the One.

Iqbal rejected Hellenic-Persian mysticism as self-mystification and nihilism that shut its eyes to the facts of life. He was also critical of Hellenic thought as the world is seen either as a necessary emanation in neo-Platonism. In his view, matter was a form of spirit, which was the ultimate principle. He was critical of Plato because for him the world was an imperfect reflection of the world of ideas and therefore unreal, and matter existed as an independent principle, not derived from the Ideas. ${ }^{15}$

\footnotetext{
${ }^{11}$ Muhammad Iqbal, The Development of Metaphysics in Persia, (Lahore: Bazam-i Iqbal, 1964), 83.

${ }^{12}$ R.A. Nicholson, "Introduction" in Muhammad Iqbal, The Secrets of the Self: A Philosophical Poem, trans. R.A. Nicholson, (Lahore: Shaikh Muhammad Ashraf, 1955), ix.

${ }^{13}$ Latif Ahmed Sherwani (ed.), Speeches Writings and Statements of Iqbal, (Lahore: Iqbal Academy, 1995), 155.

${ }^{14}$ Muhammad Iqbal, The Development of Metaphysics in Persia, 83-88.

${ }^{15}$ Annemarie Schimmel, Gabriel's Wing a Study into the Religious Ideas of Sir Muhammad Iqbal, (Leiden: E.J. Brill, 1963), 319.
} 


\section{Two Faces of Reason's Appearance, the Mystical Experience, and the Self Annihilation}

By scrutinizing the content of his magnum opus work, The Reconstruction of Religious Thought in Islam, we can generally infer Iqbal's critical notes of the nature of reason. For him, the basic and fundamental characteristic of reason from which it moves dynamically in grasping reality is ever unsatisfied with what it has achieved. Whatever thing reason has accomplished is something meaningful in a sense that reason just knows truth, with little $t$, and never knows Truth, with capital $T$. Without reason, we can never be aware of reality existing in itself as a whole. From this point, he argues that, in fact, reason has its highest form called intuition.

Reason is seen by Iqbal in two faces, i.e., its temporal appearance and its wholeness one. He calls the former reason and the latter intuition. What he means with intuition is a highest form of reason. Apparently, he approves Bergson's theory saying that intuition is actually just a kind of reason in its highest way of understanding. ${ }^{16}$ For Iqbal, reason and intuition are in fact not contrary to one another. Both emerge from the same root, need each other, and position their own function in life or in understanding something. Concerning both he says as follows:

The one grasps Reality piecemeal, the other grasps it in its wholeness. The one fixes its gaze on the eternal, the other on the temporal aspect of Reality. The one is present enjoyment of the whole of Reality; the other aims at traversing the whole by slowly specifying and choosing up the various regions of the whole for exclusive observation. Both are in need of each other for mutual rejuvenation. Both seek visions of the same Reality which reveals itself to them in accordance with their function in life. ${ }^{17}$

Iqbal states that reason indeed presents the reality in its definitions or definite specifications or terminations, but the facts of those definite specifications, which due to these it is not important and necessary to say whether reason is approximation or not, fundamentally shows that reason has the basic character, i.e., that it cannot eventually feel satisfied with what it has obtained, and therefore it always want to grasp something better, more ultimate, and more perfect.

The type of logical understanding of reason is generalization based on equations. Result of the generalization in the eyes of its terminations seem to be only as the merely illusive entities or what Kierkegaard calls approximation. ${ }^{18}$ But, for Iqbal, in terms of its

\footnotetext{
16 Muhammad Iqbal, The Reconstruction of Religious Thought in Islam, (New Delhi: Nusrat Ali Nasri for Kitab Bavan, 1981), 8.

${ }^{17}$ Ibid.,2-3.

${ }^{18}$ Approximation he means is an uncertain probability given by reason. Reason justification is approximation in character because it can be questioned again, and always be the possibility of error; it cannot dismiss the hesitation. Reason can never give us certainty but just possibilities. In action, it is not reason that gives an
} 
journey toward eternity it implies its pure character, to undergo the fut ure infinitely to grasp the ultimate Reality, the true Truth. In its purer and higher movement or progress, reason is precisely able to accomplish the ultimate Reality pervading everything. In that movement, which reason has a desire to show itself, various senses of those terminations are but just moments. Therefore, the basic feature of reason is dynamic in nature, not static, and shows the nature of the very Unbegun and Unfinished, as seed that from the beginning is indeed contained in itself the organic unity of a tree which is real in front of us. ${ }^{19}$ Which being aware of and capturing this is reason in its highest form, in its fundamental character, that is, intuition itself.

From these two kinds of reason, Iqbal derives the notion of two kinds of human experiences. The first human experience is the normal experience, and the second one is the mystical experience. The normal experience is related to the first form of reason, whereas, the mystical experience can only be understood by the second form of reason, that is, intuition or reason in the highest form.

The normal experience of human being is the experience that subjects to the rational interpretation of empirical experience of the external world. The mystical experience is human experience subjecting to the interpretation of human knowledge concerning his internal world, particularly his internal experience of God. ${ }^{20}$ It can be inferred that what Iqbal calls the normal experience is the human experience of the external world or the empirical world, whereas, the mystical one is the human experience of the internal world.

In elaborating the mystical experience, Iqbal mentions the five main characteristics building it. Firstly, the mystical experience is immediate. Secondly, it is the internal consciousness of reality as an unanalyzable wholeness. Thirdly, the mystical state is an intimate association to a Unique Other Self. Fourthly, the mystical states prefer to feeling than thought, and hence it is directly experience that cannot be communicated as a whole as it exists in the subject's immediate experience. Finally, Terakhir, the mystical states give the consciousness of the unreality of serial time. ${ }^{21}$

In fact, the mystical experience that is immediate in nature does not differ from other levels of human experience Iqbal mentions as the normal experiences. All experience is

exact or certain decision but will. He said that my reason always place me in a state of indifference, because it can only say to me you can just do this or that. In the situation, he said, I have no rational justification to act. In other words, reason in respect of the decision of what I shall do can just give the possibilities.Soren Kierkegaard, Concluding Unscientific Postscript, trans. by David P. Swenson and Walter Lowrie, (Princeton: Princeton University Press, 1968), 103, see also Louis P. Pojman, The Logic of Subjectivity: Kierkegaard's Philosophy of Religion, (Alabama: the university of Alabama Press, 1984), 30.

${ }^{19}$ Ibid., 6.

${ }^{20}$ Fazlur Rahman, "Iqbal and Mysticism" in M. Raziud-Din Siddiqi, et. all., Iqbal as a Thinker (Lahore: SH. Muhammad Ashraf, 1991), 200.

${ }^{21}$ Mohammad Iqbal, The Reconstruction of Religious Thought in Islam, $17-21$. 
immediate. As the state of normal experience is subject to the interpretation of sense-data for human knowledge of the external world, so the state of mystical experience is subject to the interpretation for internally human knowledge of a Unique Other Object, that is, God. Thus, all experience is direct, its difference is merely the object experienced. Both the normal and mystical experiences have the similar character, i.e., there is direct contact to the experienced object. The mystical experience is not a system of concepts mutually related to one another. It has no reference to experience. ${ }^{22}$ Thought stemmed from pure abstractions of reason, in Iqbal's opinion, tends to be not directly related to experience. It is this thought that emerges the concepts then theoretically claimed as the objective truth of a reality understood by subject. Then this understanding determines and dictates the human experience as if the human experience never move. This view obviously matches with the principle of existentialism that existence precedes essence. For Iqbal, experience of a thing always come before the concepts of it. The mystical experience is the immediate association with God, a Unique Other Self. It can never be replaced by any indirect association with God, that is, the human association with the concepts of God. The human intimately immediate relationship to God differs from the human relationship to the concepts of God.

The second point of mystical experience is the unanalyzable wholeness. It wholly captures a reality as the internal awareness behind the intimately human association with God. The consciousness of wholeness is unanalyzable and cannot be grasped as the objective concepts. The content of a mystical experience that is experienced by individual cannot be objectively depicted to others. If the normal experience can be analyzed and constructed in the rational concepts because of its relatedness to the sensible experiences, the mystical experience cannot be analyzed because of its independence of sensible experiences. It does not mean that the normal and mystical experiences are separated one another, but they just describe the way of realizing a thing differently. It means that the state of normal knowledge of human being in comprehending and realizing a thing or a reality in partial or in piecemeal way related to the consciousness of serial time, and in the state of mystical knowledge, he understands and realizes it as the total passage of Reality in which all diverse stimuli merge into one another and form a single unanalyzable unity in which the ordinary distinction of subject and object does not exist. ${ }^{23}$

The mystical state is a moment of the very intimate association with a Unique Other Self. This Self is Unique, beyond others, transcending, and momentarily suppressing the private personality of an experiencing subject. The content of mystical state, or the state of the experience of association with a Unique Other Self, is highly objective in the capture of subject who experience Him, but when it is rationally explained and expressed by using of

\footnotetext{
${ }^{22}$ Ibid., 17.

${ }^{23}$ Ibid., $17-18$.
} 
the human normal experience, it cannot be objective any more. The mystical state, for Iqbal, cannot be regarded as a mere retirement into the mists of pure subjectivity. The mystical state is always passive. It does not prove that the otherness of a Unique Self experienced can be tested in the human normal experience. For Iqbal, the passive state, to some extent, is similar to the normal experience, as in the human social relationship to other human beings. Man can only realize the self-presence of other human being, can merely clarify as far as the physical movements, the gestures, and the language expressions. Man never own the feeling of experiencing the thoughts of other selves. ${ }^{24}$

The mystical conditions are more like feeling than thought. What Iqbal means is that the mystical experience is untouchable, cannot be communicated, and cannot be transmitted to other person, except in the expressive forms of the languages of normal experience, but it still does not describe the true content of mystical experience as the mystic himself experienced. It cannot be communicated because of the fact that the mystical experience, in fact, is more like inarticulate feeling than articulate one that cannot be touched and cannot be revealed by the discursive understanding. ${ }^{25}$ The meaning of untouchable and unrevealed by the discursive understanding is that the feeling can be expressed in the discursive thought, but the result of the discursive thought can never be identical with the true content of the feeling. Iqbal implies this sense with the following words:

It must, however, be noted that mystic feeling, like all feeling, has a cognitive element also; and it is, I believe, because of this cognitive element that it kends itself to the form of idea. In fact, it is nature of feeling to seek expression in thought. It would seem that the two - feeling and idea - are the non-temporal and temporal aspects of the same unit of inner experience. ${ }^{26}$

Since the logical thought or abstraction is not the temporal aspect of the human inner experience, it can never wholly express the non-temporal aspect of it. Regarding this, Fazlur Rahman says that feelings find the bigger relief in a metaphor rather than in abstraction. ${ }^{27}$ This comment precisely asserts that the logical abstraction in Iqbal's mind is a kind of "the hole of light" from which man sees the wholeness of Reality captured in the human existential experience. Hence, the logical abstraction can never represent the experience felt and experienced by human being. The human existential experience of Reality is wider than the logical abstraction of it.

\footnotetext{
${ }^{24}$ Ibid., $18-19$.

${ }^{25}$ Rahman, "Iqbal and Mysticism”, 204 - 205.

${ }^{26}$ Mohammad Iqbal, The Reconstruction..., 20.

${ }^{27}$ Rahman, "Iqbal and Mysticism”, 206.
} 
The mystical experience gives the consciousness of the unreality of serial time. Iqbal seems to hold that there are two worlds of human life, i.e., the world of serial time and that of non-serial time. These two world are not two world separated at all, because the mystical state in term of its uniqueness in some regards still relate to the ordinary experiences. Experiencing the non-serial time world does not mean that the conclusion of the development of human self through his entire experience of life is leaving the concrete world, the serial time world, but what experienced is for realization of the self-existence developed in the world that is not merely in serial time condition. It indicates that in the human life there is a kind of infinity meaning of mankind, or in other words, the humanity is dynamic in its meaning. It means that the meaning of humanity is not an instant product that the next meaning is reduplicated. Behind the dynamism of the meaning of humanity, there is the principle of uniqueness of human self. ${ }^{28}$

The Iqbal's exposition of the characteristic of mystical experience denotes his insight of mysticism. Mysticism, for Iqbal, is close to the Eveyn Underhill, that is, the quest for the intimate relationship to God as the embodiment of metaphysical thirstiness. The human experience of the real, physical, and vital world is the human existential-faktual world. The disclosing of metaphysical world within the human consciousness of encounter with God is not the disappearance of the human faktual, concrete, and existential world, because the mystical experience is precisely asserting the unique self as a form of absorbency of the uniqueness of the other Self by human being in order to assert his uniqueness within the life of his concrete-existential world.

In his work, The Reconstruction of Religious Thought in Islam, and more firmly in Asrār-i Khūdi, as mentioned by Umar Ibrahim Vadillo, Iqbal describes his mysticism as a representation of the theory of self that is the strong cursing and condemnation to the selfnegating quietism. ${ }^{29}$ Iqbal obviously denies the quietism by sacrificing and refuting the self individuality. A true sufis is measured by discovering his true self different with the Other Self, not measured by the disappearance or meltdown of his self into the Self of God.

Iqbal knew well the sufistic traditions, either the Persian and Semitic mysticism as termed by L. Massignon or the Asiatic mysticism Annemarie Schimmel as addition to the two types of mysticism. The kind of Persian mysticism is in general characterized by the

\footnotetext{
${ }^{28}$ Mohammad Iqbal, The Reconstruction ..., $21-23$.

${ }^{29}$ Umar Ibrahim Vadillo, The Islamic Deviation ..., 581, Vadillo himself values such Iqbal's view a total misunderstanding of the mystical goal, and he does not regard Iqbal as a mystic, except as one who empathetic to Islamic esoterism see 586. The Vadillo's own measure of assessing whether Iqbal knows mysticism or not is also not clear and even it is not clear as well whether Vadillo himself is the supporter the self-negating quietism or not. For writer, the clear thing is that there is no problem with mysticism as the encounter experience as the embodiment of human metaphysical longing of the divine world the different is merely the product coming after the encounter, whether the mystical human being should loss his selfness or not
} 
essential monism or wahdah al-wujū $d$ that of Semitic one is in general marked by the testimonial monism or wahlah al-shuhūd, and that of the Asiatic mysticism signed by carelessness of the beauty and love of God, because God is comprehended more as the fully undepictable. The essential monism usually tend to the pantheistic interpretations of the mystical experiences. In this kind of monism, the God's transcendence becomes blurr and the human selfness as well as his uniqueness are negated. Different from the essential monism, the testimonial monism talks more about the Greatness and Beauty of God. This kind of monism understands the unity of man and God not as the unity of being or wahdah al-wujū $d$, such as God is all and all is God, but the unity of testimony, i.e. that all beings or existences are witnesses of the God's existence. If the essential monism tends to the pantheistic interpretations, the testimonial monism prefers to the panentheistic interpretations. Different from the two kinds of mysticism, the Asiatic mysticism considers both essential and testimonial monism as merely beginning step of the mystical ladders. ${ }^{30}$ The highest mystical level is not the unity of both being and testimony, but God comprehended as self resolved into the Ultimate in term of Buddhism, Nirvana, or God seen as the undescribed "Nothingness". In doing so, God Self and human self disappear, because of being negated.

It seems that Iqbal does not agree with the kind of Persian and Asiatic, and instead, he prefers to the kind of Semitic mysticism. He himself underwent those tree mystical traditions. In his own land, he witnessed the Islamic mysticism strongly influenced by the Hinduist and Buddhist mysticism. Those who sufis spread variety of religious belief and practice fleeing from the business of the worldly life. They torture themselves and "kill" their egos of selfness as human being that should live with the individual uniqueness. Even some of them did the practice of syirk, such as worshiping and adoring the gods statues or pagans to ask for the certain needs. For example, the worshiped and adored the god of Chachak in order to avoid the smallpox or chicken pox. Dara shukuh, a Sufis figure of thariqah (a religious path of mysticism) of Qadiriyyāt wa Naqsyabandiyyāt, statedthat the Book of Upanisad, the exegesis of the Book of Veda in Hinduism, is the Hidden Book having the same meaning of the Qur'an. His work titled Majma' al-Bahrayn injects the messages of Hinduism, particularly Upanisad, into his sufistic teaching. ${ }^{31} \mathrm{Hindu}$ and Buddha, recognized by Iqbal, specifically the idea of Buddhism on Nirvana and the Vedantic doctrine of pantheism in Hinduism, strongly influenced the mystical practices of Islamic Sufis of India in particular and of Asia in general killing the human selfness and fleeing

\footnotetext{
${ }^{30}$ Annemarie Schimmel, Gabriel's Wing, 365 - 366.

${ }^{31}$ Marcia K.Hermansen, "Muhammad Iqbal, Islam as a Moral and Political Ideal”, in Charles Kurzman (ed.), Modernist Islam, 1840 - 1940 (Oxford, New York: Oxford University Press, 2002), 305 - 307, Sayyed Hossein Nasr, Sufi Essays (London: George Allen \& Unwin Ltd., 1972), 141 - 142, and Harun Nasution, Pembaharuan dalam Islam: Sejarah Pemikiran dan Pergerakan (Jakarta: Bulan Bintang, 1991), 157.
} 
from the world. Indeed, their ideas and notions introduced and taught the world of nonspatial time, and this is positive for every mystical experience of whatever kind of mysticism. Nevertheless, the non-spatial time then is considered as the goal of mystical activity. And they saw it as illusion and mirage. This view, of corse, has an implication to the spiritual egoism and does not have an activism of mission of humanity at all. ${ }^{32}$ Iqbal refutes mysticism illusively and negatively seeing the real world of human being.

Of the Persian tradition, Iqbal is one of thinkers who had traversed its metaphysics and then was chosen as the metaphysical object of his thesis research titled Development Metaphysics in Persia. In this work, he had explored the spirituality of Persian people including the mystical philosophies of the great Persian thinkers such as Mulla Sadra and Hadi Sabzawari. Iqbal valued that both Mulla Sadra and Hadi Sabzawari were purely neoplatonism. ${ }^{33}$ Because of the strong influence of neo-platonism to the Persian thinkers and mystics, the Persian mysticism was dominated by pantheistic color. Therefore, the color of its mystical philosophy is essential monism. This tendency then kept giving the influence to the Persian-muslim philosophers and mystics. Iqbal noted this tendency and assumed that it was the Hellenistic-Persian mysticism, i.e., that of Persian people that had been contaminated particularly by Platonism and neo-Platonism, that was responsible for dominance of the practices of pantheistic mysticism in the Islamic world. This kind of mysticism encourages people to ignore and value nothing the actual-concrete realities of human beings, and then to direct their insights to what they describe as "illumination", reality emerged from the overworked brain cells. ${ }^{34}$

A notion, according to Iqbal, that cannot be accepted from the Islamic mysticism is that of fana', i.e., the mystical step in which self-obliteration and self-annihilation occur. In the fana' condition, even individual is unable to identify himself anymore. And in Jã $\tilde{\text { d }}$ Nãmah, Iqbal showed his denial of fana' in Islamic mysticism interpreted as complete annihilation of the self as can be read in this part of his poem:

You who seek your goal in annihilation

Non-existence can never discover existence ${ }^{35}$

This words assert his view assessing that kind of mysticism merely present as self mystification and nihilism. Its teaching eliminates the vitality of human individuality in order to reach the actual-concrete reality. And the doctrine such as wahdah al-wujü $\mathrm{Ibn}$

\footnotetext{
${ }^{32}$ Khalifa Abdul Hakim, "Rumi, Nietzsche, and Iqbal", in M. Raziud-Din Siddiqi, et. all., Iqbal as a Thinker (Lahore: SH. Muhammad Ashraf, 1991), 128.

${ }^{33}$ Annemarie Schimmel, Gabriel's Wing ..., 335.

${ }^{34}$ See Iqtidar Husain Siddiqui, "Iqbal and Islamic Tasawwuf (with Special Reference to Ibn Al-'Arabi's Sufism" in Journal Islam and The Modern Age, May-August, 1987, 98-99.

${ }^{35}$ Muhammad Iqbal, Jāvid-Nāma, trans. Arthur J. Arberry (London: George Allen \& Unwin LTD., 1966), 101, see also Muhammad Iqbal, Jãvĩd Nãmah, 739.
} 
'Arabi dan al-ittihãd Abu 'Ali al-Sindi dan Abu Yazid al-Bistomi will only solve and sink the uniquely self individuality of human being into the Ultimate Reality. ${ }^{36}$ Iqbal seriously sees the danger of this kind of mysticism as contained in the doctrine of fana', because it destroys the human personality and individuality, and even, for him, its danger exceeds the danger of the destroying of Baghdad. ${ }^{37}$

The teaching of Islamic mysticism also denied by Iqbal because of the reason of denying self-individuality is what in sufistic sense called tark, that terminologically means to leave all things and to fully submit to God. Then this self-annihilation culminates in tark al-tark, that means to avoid all things, even to avoid from willingness to avoid, a kind of quietism avoiding the worldly life. In fact, the true teaching of tark as mentioned in his work, Bãl-i Jibrĩl,

The perfectness of tark does not avoid water and clay soil

The perfectness of tark is the subjecting all things to sky and earth ${ }^{38}$

The true concept of tark, he means, is not to avoid from the worldly business born and created (symbolized by water), and not to stay away from social intercourse of human beings as well but that the escalation of human personality developing the fully inner possibilities and united with God in the unity of will, being able to be spiritual ruler of the world. ${ }^{39}$ Here Iqbal seems to give the meaning of tark that human being in high level of spirituality ought to surpass the worldy limitedness and he does not will as other people generally will.

\section{E. Being Active Human, not Passive One, to Change and Form the World Activity as the Implication of Iqbal's Philosophical Criticism of Mysticism}

Iqbal's sharp critique of pantheistic-Islamic mysticism affirms a co-existential relationship of God and human being in which the existence of God and that of human being are obviously different. There is no self-obliteration or self-disappearance of human being in God existence. Iqbal's view of God in relation to the universe including human being is much far different with the pantheistic view penetrating the Islamic sufism characterized by

\footnotetext{
${ }^{36}$ Balraj Puri, "Modernisation of Islamic Tradition by Iqbal," in Journal Islam and The Modern Age, May, 1984: 111, see also Annemarie Schimmel, Gabriel's Wing, 367.

${ }^{37}$ Muhammad Iqbal, Maktûbãt-i Iqbal, ed. Sayid Nazir Niazi (Karachi: Iqbal Academy, t.t.), 203, as quoted Annemarie Schimmel, Gabriel's Wing, 367.

${ }^{38}$ Muhammad Iqbal, Bãl-i Jibrĩl(Lahore: t.p., 1936), 64 as quoted by Annemarie Schimmel, Gabriel's Wing, 368.

${ }^{39}$ Ibid.
} 
self-annihilation or self-negation. The pantheists maintain that God is identical with the strength of entire egos or all elements of the universe "collected" in a whole union. ${ }^{40}$

The fundamental reason of Iqbal's refutation of the pantheistic sufism is the disappearance of muslim's individuality into the individuality of the Ultimate Reality at the moment of direct contact to Him, so that the human individuality and the God one cannot clearly differentiated. He regards the Islamic-pantheistic mysticism as the main source of the birth of essentialist and nihilistic human existence and religiosity destroying the capacity of human individuality to actively rethink, remade, and recreate the world or the condition of world life. In other words, it can be said that the pantheistic-Islamic religiosity sees a muslim's individuality as a barrier of spiritual climbing. The side of individuality of the process of being an active-creative muslim should be destroyed for the sake of reaching the highest spiritual experience, i.e., the uniting experience with God. ${ }^{41}$ The kind of muslimmystics' uniting experience with God implies that the process of being religious and being human quits and completes,

Being a Muslim by avoiding the actual-concrete life and by fleeing from the worldly business as purposed by that Sufism indicates a passive existence of being a muslim, and hence denotes a spiritually egoistic religiosity. Iqbal captures that mysticism of Sufism in general impresses, as shown by its term, "a life-denying" and "fact-avoiding attitude of mind", ${ }^{42}$ but in his thought, not all Islamic mysticism fall in this kind of mysticism. For him, the truly Islamic mysticism is the prophetic one as epitomized by the Prophet Muhammad pbuh in his concrete historicity. The difference of the two kinds of mysticism is that even though both the pantheistic and prophetic mysticism undergo the experience of encounter and unity with the Ultimate Reality, but the former refuting the real life regards the experience as the peak goal of religiosity, whereas the later considers it as the spiritually discovery of a new self that becomes the starter and pusher of a muslim's creation of selfactualization activating, changing, and moving the human concrete-existential life. The statement is withdrawn from Iqbal's words as follows:

"The mystic does not wish to return from the repose of 'unitary experience' and even when he does return, as he must his return does not mean much for mankind at large. The prophet return is creative. He returns to insert himself into the sweep of time with a view to control the forces of history and thereby to create a fresh world of the ideals. For the mystic the repose of 'unitary experience' is something final; for the prophet it is the awakening, within him, of world-shaking psychological forces,

\footnotetext{
${ }^{40}$ Muhammad Iqbal, The Reconstruction of Religious Thought in Islam, 111.

${ }^{41}$ Ibid.

${ }^{42}$ Ibid., 171.
} 
calculated to completely transform the human world. The desire to see his religious experience transformed into a living-world force is supreme in the prophet." 43

In the statement, it clearly seems that self-discovery in the highest meaning in front of God is more a completion of human selfness to exist in the human concrete life as the source of life mover. A Muslim's religiosity through a kind of self does not like an action without personal involvement. By avoiding the human concrete life, a muslim does not only defeat, but also being unable to control the concrete world of human life and to kill his true selfness because of undergoing life without his own choice and actualization. A muslim's religiosity only will a life going up to the sky of spiritual realm without a place of stand on the earth of human actual-concrete realm in which his spirituality ought to be expressed and actualized. From Iqbal's point of view, in that Muslim's religiosity there is no existential meaning there is just passivity for the sake of a quietness. This model of religiosity is obviously essentialist, because it understands the process of religiosity as a journey that will stop at a harbor of termination called that "unitary experience" and after come to the harbor, there is no journey anymore to do.

Religiosity should always be a continuation of expression and actualization of human selfness processed to be religious. The continuation is a form of everlasting process of finding the human individuality within "unitary experience" with God's Individuality. This experience affirms that His never ending creations that one of them is the creation of universe and human being indicate the unlimitedly creative work of Great Individuality. This regard also affirms in human self of a Muslim as the limited ego that the true religiosity is a process of action in continuously connecting himself to God by always showing and sharpening his individuality in this life. By entering into the world of human life generally and that of Muslims' lives specifically, the true Muslim religiosity shows an action that is able to control and direct the collective strengths of humanity, and does not dissolve in the existing collectivism. The following Iqbal's words describe that explanation:

"The prophet may be defined as a type of mystic consciousness in which 'unitary experience' tends to overflow its boundaries, and seek opportunities of redirecting or refashioning the forces of collective life. In his personality the finite center of life sinks into his own infinite depths only to spring up again, with fresh vigour, to destroy the old, and to disclose the new direction of life."

\footnotetext{
${ }^{43}$ This statement, as recognized by Iqbal, is inspired by the words of a great religious-muslim figure, Abdul Quddus from Ganggoh, who makes the psychological difference of mystically consciousness type between the mystics in general and the prophet.. Look Ibid., 118.

${ }^{4}$ Ibid., 119.
} 
Here it clearly seems in Iqbal's thought that collectivism is something historical and natural, and it cannot be avoided. Although collectivism seems to be historical and natural, it is more a product of continuous actualization of individuals. It is not the harbor of termination.

Iqbal argued that a rightly focused man should unceasingly generate vitality through interaction with the purposes of the living God. The Prophet Muhammad had returned from his unitary experience of God to let loose on the earth a new type of manhood and a cultural world characterized by the abolition of priesthood and hereditary kingship and by an emphasis on the study of history and nature. A Muslim who has 'unitary experience' ought to return to the earth to continuously remake and recreate new and fresh world of factual and empirical human life.

\section{F. Conclusion}

Iqbal's thought of Islamic mysticism describes the consistency with his philosophy of ego or self. His Islamic mysticism strongly refute the notion of fanā' (self-dissipation into God's Self) and boldly deny the passive selfness. It is the active selfness that is a strong condemnation of the self-negating quietism of classical Islamic mysticism. The achievement of the active selfness, as a fruit of the unitary experience of human's selfness and God's Selfness, is not perfection and peaceful rest, but, in reverse, the continuously and never ending self-actualization of human being to remake and refresh the worldly factual life. The Iqbal's Islamic mysticism cannot be terminated in perfection and spiritual peace that are attained by passive absorption in contemplation of God and divine things. Iqbal and his admirers steadily maintain that creative self-affirmation is a fundamental Muslim virtue. 


\section{Bibliography}

Badawi, A.R., Tārỉkh al-Tașawwuf al-Islāmiy, Makkah: Dār al-Ma’̄arif, 1975.

Bowering, Gerhard, "Iqbal: A Bridge of Understanding Between East and West" in Journal of South Asian and Middle Eastern Studies, vol. I, no. 2, Dec. 1977.

Danusiri, Epistemologi dalam Tasawuf Iqbal, Yogyakarta: Pustaka Pelajar, 1996.

Hakim, Khalifa Abdul, "Rumi, Nietzsche, and Iqbal", in M. Raziud-Din Siddiqi, et. all., Iqbal as a Thinker, Lahore: SH. Muhammad Ashraf, 1991. , "Renaissance in Indo-Pakistan: Iqbal" in M.M. Sharif (ed.), $A$ History of Muslim Philosophy, vol. II, Jerman: Ottohorrosowitz, 1996.

Hermansen, Marcia K., "Muhammad Iqbal, Islam as a Moral and Political Ideal", in Charles Kurzman (ed.), Modernist Islam, 1840 - 1940. Oxford, New York: Oxford University Press, 2002.

Iqbal, Muhammad, Bãl-i Jibrĩl. Lahore: t.p., 1936.

, Javid-Nama, trans. Arthur J. Arberry, London: George Allen \& Unwin LTD., 1966.

, The Development of Metaphysics in Persia, Lahore: Bazam-i Iqbal, 1964.

, The Reconstruction of Religious Thought in Islam, New Delhi: Nusrat Ali

Nasri for Kitab Bavan, 1981.

, The Secrets of the Self: A Philosophical Poem, trans. R.A. Nicholson, Lahore: Shaikh Muhammad Ashraf, 1955.

Keizer, Mervin M. and Sahibzada, Nasem, "Iqbal: A Profile" in Journal of South Asian and Middle Eastern Studies, vol. I, no. 2, Dec. 1977.

Kierkegaard, Soren, Concluding Unscientific Postscript, trans. by David P. Swenson and Walter Lowrie. Princeton: Princeton University Press, 1968.

Malik, Hafeez dan Malik, Linda P., "Filosof-Penyair dari Sialkot" in Ihsan Ali Fauzi and Nurul Agustina (trans. \& eds.), Sisi Manusiawi Iqbal. Bandung: Mizan, 1992.

Nasr, Sayyed Hossein, Sufi Essays, London: George Allen \& Unwin Ltd., 1972.

Nasution, Harun, Islam Ditinjau dari Berbagai Aspeknya, Jakarta: UI Press, 1985.

Nasution, Harun, Pembaharuan dalam Islam: Sejarah Pemikiran dan Pergerakan, Jakarta: Bulan Bintang, 1991.

Pojman, Louis P., The Logic of Subjectivity: Kierkegaard's Philosophy of Religion. Alabama: the University of Alabama Press, 1984.

Puri, Balraj., "Modernisation of Islamic Tradition by Iqbal," in Journal Islam and The Modern Age, May, 1984.

Rahman, Fazlur. "Iqbal and Mysticism" in M. Raziud-Din Siddiqi, et. All., Iqbal as a Thinker, Lahore: SH. Muhammad Ashraf, 1991. 
Roswantoro, Alim, Gagasan Manusia Otentik dalam Eksisntensialisme Religius Muhammad Iqbal, Yogyakarta: Idea Press, 2009.

Schimmel, Annimarie. Gabriel's Wing a Study into the Religious Ideas of Sir Muhammad Iqbal, Leiden: E.J. Brill, 1963.

, Gabriel's Wing a Study into the Religious Ideas of Sir Muhammad Iqbal, Leiden: E.J. Brill, 1963.

Sherwani, Ahmed (ed.). Speeches Writings and Statements of Iqbal. Lahore: Iqbal Academy, 1995.

Siddiqui, Iqtidar Husain, "Iqbal and Islamic Tasawwuf with Special Reference to Ibn Al'Arabi's Sufism" in Journal Islam and The Modern Age, May-August, 1987.

Singh, Iqbal, The Ardent of Pilgrim: An Introduction to the Life and Work of Muhammad Iqbal, Calcuta: Orient Longmans, 1951.

Taftāzānī, Abū al-Wafā, Al-Madkhal Ilā al-Taṣawwuf al-Islāmīi, Kairo: Dār al-Thaqāfah, 1979. 
